\title{
0 microplancton do Atlantico nas imediações de Mar del Plata pelos
}

\author{
Drs. ARISTIDES MARQUES DA CUNHA e O. DA FONSECA.
}

(Com 2 figuras no texto.)

\begin{abstract}
O trabalho que ora publicamos é o resultado de pesquizas qualitativas feitas sobre material que fôra confiado a um de nós pelo Professor Dr. ANGEL GALLARDO, director do Museu Nacional de Historia Natural de Buenos Aires; ao ilustre naturalista argentino agradecemos a oportunidade que nos ofereceu de estudar assunto até agora ainda não pesquizado.

As diversas amostras de plancton foram colhidas a bordo do navio "PATRIA", á distancia variavel entre 5 e 10 milhas da costa nas aguas fronteiras a Mar del Plata, mais ou menos a $380^{\circ}$ de latitude Sul e 570 e 30' de longitude, a este de Greenwich. Parte desse material incluia apenas animais nuacroscopicos, copépodos, isopodos e chetognatas, cujo estudo não empreendemos; a maioria dele, entretanto, era constituida por microplancton em que, alén de copépodos en fases diversas de desenvolvimento, de larvas Pluteus de echinodermas e de larvas de moluscos, encontravam-se fórmas de diatomaceas, peridineos, tintinideos e silicoflajelados; só os representantes destes quatro ultimos grupos fazem objeto do presente trabalho.

Conseguimos determinar 52 especies, das quais uma apenas consideramos nova; dessa especie unicamente, apresentaremos descrição e figura; a maioria das restantes já constituiu assunto de trabalho sobre o microplancton da baía do Rio de Janeiro, realizado, em colaboração com um de nós, pelo Dr. J. GOMES DE FARIA; sobre esses planctontes já aqui assinalados nenhuma outra indicação se torna necessaria, constituindo informação suficiente a lista que abaixo apresentamos.

\section{Zooplancton.}

\section{Tintinnodea.}

1 - Tintinnopsis beroidea Stein, 1867.

2-Tintinnopsis platensis, n. sp.

Descrição-Carapaça cilindrica, estreitando-se bruscamente no inicio de seu terço posterior em que adquire perfil ojival; do vertice da ojiva parte um prolongamento caudal longo, afilado e mais ou menos acentuadamente curvo. Particulas esparsas de silica revestem os tres quartos anteriores, correspondentes á parte cilindrica e ojival da carapaça. A curvatura aparente do prolongamento caudal varia con a posição do animal,
\end{abstract}


ás vezes simulando ele ser completamente réto.
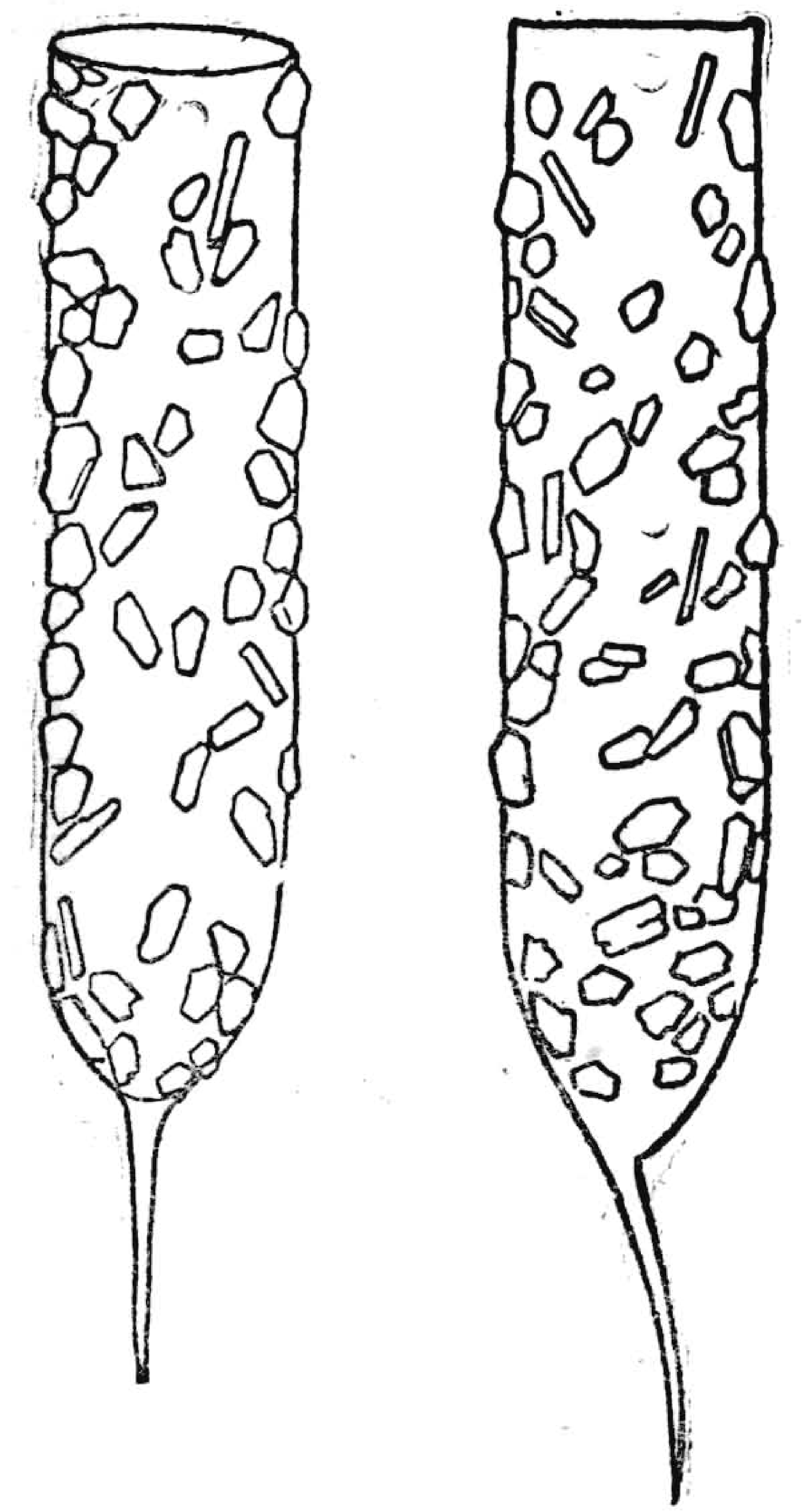

Dimensões-Comprimento tolal $250 \mu$; comprimento do prolongamento raudal $60 \mu$; largura da parte cilindrica $45 \mu$.

Habitat-Atlantico Sul, imediações de Mar del Plata.

II. Phytoplancton.

\section{Dinoflagellata.}

3-Dinophysis homunculus Stein,, 1883. 4-Dinophysis ovium Schuett, 1895.

5-Glenodinium trochoideum Stein, 1883.

6-Diplopsalis lenticula Bergh, 1881.

7-Peridinium conicum (Gran, 1900) Gran.

8--Peridinium depressum Bailey, 1885.

9-Peridinium divergens Ehrenberg, 1840.

10-Peridinium oceanicum Vanhoeffen, 1897.

var. oblongum Aurivillius.
11 -Peridinium obtusum (Karsten, 1906) Fauré-Fremiet.

12-Peridinium pentagonum (Gran, 1900) Gran.

13-Ceratium furca (Ehrenberg, 1859).

14-Ceratium fustss (Ehrenberg, 1833) Dujardin.

15-Ceratium tripos (Mueller, 1781).

\section{Bacillariophyta.}

16-Paralia sulcata (Ehrenberg, 1837).

17 -Siephanopyxis appendicula Ehrenberg, 1854.

18-Skeletonema costatum (Greville, 1866).

19-Lauderia glacialis Gruenow, 1884.

20 - Leptocylindrus danicus Cleve, 1889.

21 - Guinardia flacida Castracane, 1886.

22 - Coscinodiscus excentricus Ehrenberg, 1839.

23-Coscinodiscus radiatus Ehrenberg, 1839.

24 -Actinoptychus splendens (Ehrenberg, 1844).

25-Actinoptychus vulgaris Schumann.

26-Rhizosolenia alata Brightwell, 1858. var. genuma Gran, 1911.

var. indica Peragallo, 1892.

27-Rhizosolenia calcar-avis Schultze, 1858.

28 - Rhizosolenia robusta Normann, 1861.

29-Rhizosolenia schrubsolei Cleve, 1881.

30-Rhizosolenia setigera Brightwell, 1858.

31 - Bacteriastrum furcatum Schadb., 1854.

32 -Chaetoceras contorctum Schuett, 1888.

33-Chaetoceras curvisetum Cleve, 1889.

34 -Chaetoceras didymum Ehrenberg, 1845.

35-Chotoceras holsaticum Schuett, 1895.

36 -Chaetoceras laciniosum Schuett, 1894.

37-Chaetoceras pelagicum Cleve, 1873.

38-Chaetoceras schuetti Cleve, 1894.

39-Chaetoceras subtile Cleve, 1896.

40-Chaetoceras weissfloeg ii Schuett, 1895.

41 -- Hemiaulus sinensis Greville, 1865.

42-Cerataulina bergonii Peragallo, 1890.

43-Biddulphia favus (Ehrenberg, 1839) v. Heurck.

44-Biddulphia mobiliensis (Bailey, 1850) Gruenow. 
45-Biddulphia rhombus (Ehrenberg) W. Smith, 1844.

46-Biddulphia sinensis Greville, 1866.

47-Bellerochea malleus (Brightwell, 1858).

48-Lithodesmium undulatum Ehrenberg, 1840.

49-Ditylium brightwelli (West, 1860).
50 - Thallassiothrix nitzschioides Oruenow 1862.

51 -Asterionella japonica Cleve, 1882.

Silicoflagellata.

52-Dictyocha fibula Ehrenberg, 1839. 